\title{
LONG-TERM CHANGES OF DAUGAVA RIVER ICE PHENOLOGY UNDER THE IMPACT OF THE CASCADE OF HYDRO POWER PLANTS
}

\author{
Elga Apsite ${ }^{1}$, Didzis Elferts ${ }^{2}$, and Inese Latkovska ${ }^{1}$ \\ ${ }^{1}$ Faculty of Geography and Earth Sciences, University of Latvia, Jelgavas iela 1, Rīga, LV-1004, LATVIA; \\ elga.apsite@lu.Iv \\ ${ }^{2}$ Faculty of Biology, University of Latvia, Jelgavas iela 1, Rīga, LV-1004
}

Communicated by Māris Kḷaviṇš

\begin{abstract}
This paper presents the results of the study of long-term changes of Daugava River ice phenology, i.e. the freeze-up date, the break-up date, and the duration of ice cover from 1919/1920 to 2011/2012, under the impact of the cascade of hydro power plants. The long-term changes of ice phenology were determined by global climate warming at the turn of the $20^{\text {th }}$ and the $21^{\text {st }}$ centuries and anthropogenic activities after the year 1939. The Mann-Kendall test showed that the ice freeze-up date has a positive trend, while the ice break-up date and the duration of ice cover had negative trends. The changes were statistically significant. Data series covering twenty years before and after construction of the hydro power plants were used for assessing the impact of each hydro power plant on changes of Daugava River ice phenology parameters. The study results showed that the duration of ice cover was significantly longer in water reservoirs, i.e. the freezeup date was earlier and the break-up date was later. Downstream of dams duration of ice cover was shorter with later freeze-up dates and earlier break-up dates. The impact of hydro power plants on ice phenology parameters gradually decreased with distance down from the dams.
\end{abstract}

Key words: river ice, trends, hydro power plant, Daugava River.

\section{INTRODUCTION}

The ice regime of a river depends on climate (air temperature), hydrodynamic (flow rate), and anthropogenic (e.g., temperature of effluents input to the river, hydro-technical facilities) factors and the type of river feeding (e.g., temperature of ground water) (Šarauskienè and Jurgelènaité, 2008). However, air temperature is the main factor that regulates ice formation on rivers and lakes (Magnuson et al., 2000; Kḷaviņš et al., 2009). Studies of changes in air temperature in the Northern hemisphere during the $20^{\text {th }}$ century indicate that warming of the climate occurred in the period 1920-1940 followed by a period of worsening of the climate conditions. During the last few decades before the turn of the $21^{\text {st }}$ century, however, a more rapid increase in air temperature and warming of the global climate was observed (Anonymous, 2007). Many studies have shown increased duration of the ice-free period, an increasing trend in ice freeze-up dates and a decreasing trend in ice break-up dates of rivers and lakes (e.g., Magnuson et al., 2000; Šarauskienè and Jurgelènaité, 2008; Kḷaviņš et al., 2009; Solomon and Knut, 2011). Hydro-technical facilities, e.g., construction of a hydro power plant (HPP) on a river, also can affect long-term changes of ice phenology. There are very few such studies that have been carried out on the
Daugava River (Glazacheva, 1963; 1965) and on the Nemunas River (Šarauskienė and Jurgelènaitė, 2008).

The Daugava River is the largest river in Latvia and one of the largest rivers in the Baltic Sea catchment. Along its length ice freezing and breaking-up processes differ among sections, in relation to the hydrodynamic conditions of the river-bed, climate conditions, and anthropogenic activities. The ice regime of the Daugava River in the beginning of the 1930s was studied by Stakle (Stakle, 1933) and in the beginning of the 1940s by Kanaviñs (1942; 1943a; 1943b). Kanaviņš not only described the ice conditions in the Daugava River in winters of 1941/1942 and 1942/1943, but he also performed experimental research on formation of ice cover in fast-flowing reaches of rivers and on ways to release ice in the Daugava River where ice congestions and ice jams have formed (in particular, at Jēkabpils-Kegums river section). Glazacheva (Glazacheva, 1963; 1965) studied ice formation and break-up in rivers of Latvia, as well as the impact of the Kegums HPP on ice freeze-up and break-up dates. Pastors (Pastor, 1987), studied ice congestions and ice jams of the Daugava River in the JēkabpilsPliavinas section during the period from 1968 to 1982. The Daugava River has the longest data series on ice conditions in Europe, with the first records in 1530 (Kḷaviņš et al., 
2009). A pronounced downward trend of the break-up date was observed over the last 150 years, which was more clearly evident during the recent 30 years. No downward trend was observed for the initial period, which includes the Little Ice Age. The historical records show recurring periods of mild and severe winters.

The objective of this study was to describe long-term changes (1919/1920 to 2011/2012) of ice phenology of the Daugava River in winter season, in relation to the impact of hydro power plants (in Kegums, Pliavinas, and Rīga).

\section{MATERIALS AND METHODS}

Description of the Daugava River and its hydro power plants. The length of the Daugava River is $1005 \mathrm{~km}$ (325 $\mathrm{km}$ in Russia, $328 \mathrm{~km}$ in Belarus, and $352 \mathrm{~km}$ in Latvia). The total catchment area of the Daugava River is 87900 $\mathrm{km}^{2}$ of which $24700 \mathrm{~km}^{2}$ are located in the territory of Latvia. The total slope of river is $221 \mathrm{~m}$ (99 $\mathrm{m}$ of the slope in the territory of Latvia). Mean annual discharge in the Daugava River is $650 \mathrm{~m}^{3} / \mathrm{s}$. Discharges above $8000 \mathrm{~m}^{3} / \mathrm{s}$ are observed during spring high water periods and discharges below $100 \mathrm{~m}^{3} / \mathrm{s}$ are observed during summer or winter low water periods (Ziverts et al., 2000). The scheme of the Daugava River in the territory of Latvia is shown in Figure 1.

The cascade of hydro power plants was constructed on the Daugava River in the $20^{\text {th }}$ century - Plavinas HPP, Kegums HPP, and Rìga HPP (Table 1). The K,egums HPP is the oldest large HPP in Latvia, which was constructed in 1939. The Plavinas HPP was built later, and is the largest HPP in the Baltic countries. The Riga HPP, constructed in 1974, is the second largest HPP in Latvia. The cascade of HPPs controls the discharge regime, thermal conditions, and the ice processes downstream of the Daugava River.

Data and methods. Ice phenology parameters (freeze-up date, break-up date, and duration of ice cover) were investi-
Table 1

DESCRIPTION OF THE CASCADE OF THE DAUGAVA RIVER HPPS

\begin{tabular}{l|c|c|c|c|c}
\hline $\begin{array}{c}\text { Name of } \\
\text { HPP }\end{array}$ & $\begin{array}{c}\text { Distance } \\
\text { from river } \\
\text { mouth, km }\end{array}$ & $\begin{array}{c}\text { Mean an- } \\
\text { nual dis- } \\
\text { charge, } \mathrm{m}^{3} / \mathrm{s}\end{array}$ & Head, m & $\begin{array}{c}\text { Reservoir } \\
\text { storage, } \\
\text { mill. } \mathrm{m}^{3}\end{array}$ & $\begin{array}{c}\text { Year of con- } \\
\text { struction }\end{array}$ \\
\hline Pl̦aviṇas & 111 & 619 & 40 & 509 & 1968 \\
K̦egums & 67 & 620 & 16 & 157 & 1939 \\
Rìga & 36 & 640 & 18 & 339 & 1974
\end{tabular}

HPP, hydro power plant

gated in the Daugava River using records of the Latvian Environment, Geology and Meteorology Centre and the publication of the Marine Board by Stakle and Kanaviňš (1941). The used hydrological stations (HS) and observation data series are presented in Table 2.

The ice freeze-up date was assumed to be the first day of ice occurrence. The date of disintegration of the ice cover during a period with regular ice cover was assumed to be the ice break-up date. The duration of ice cover was calculated as the actual number of days during which ice occurred. Data series covering a period of twenty years before and after construction of the HPP were used to determine the effect of each HPP on ice phenology parameters. For statistical analysis, the freeze-up and break-up dates were expressed as the number of days since October 1. For trend analysis and the assessment of the HPP effect for years without ice cover, the freeze-up date was assumed to be March 10 (160 days after October 1) and the break-up date was assumed to be December 10 (70 days). These values are slightly higher/lower than the actual extreme values observed for each station.

The Mann-Kendall test (Hirsh et al., 1982; Hirsh and Slach, 1984) was used to identify trends in the annual river ice phenology parameters. The test was applied separately to each variable at each site, at a significance level of $p<0.05$.

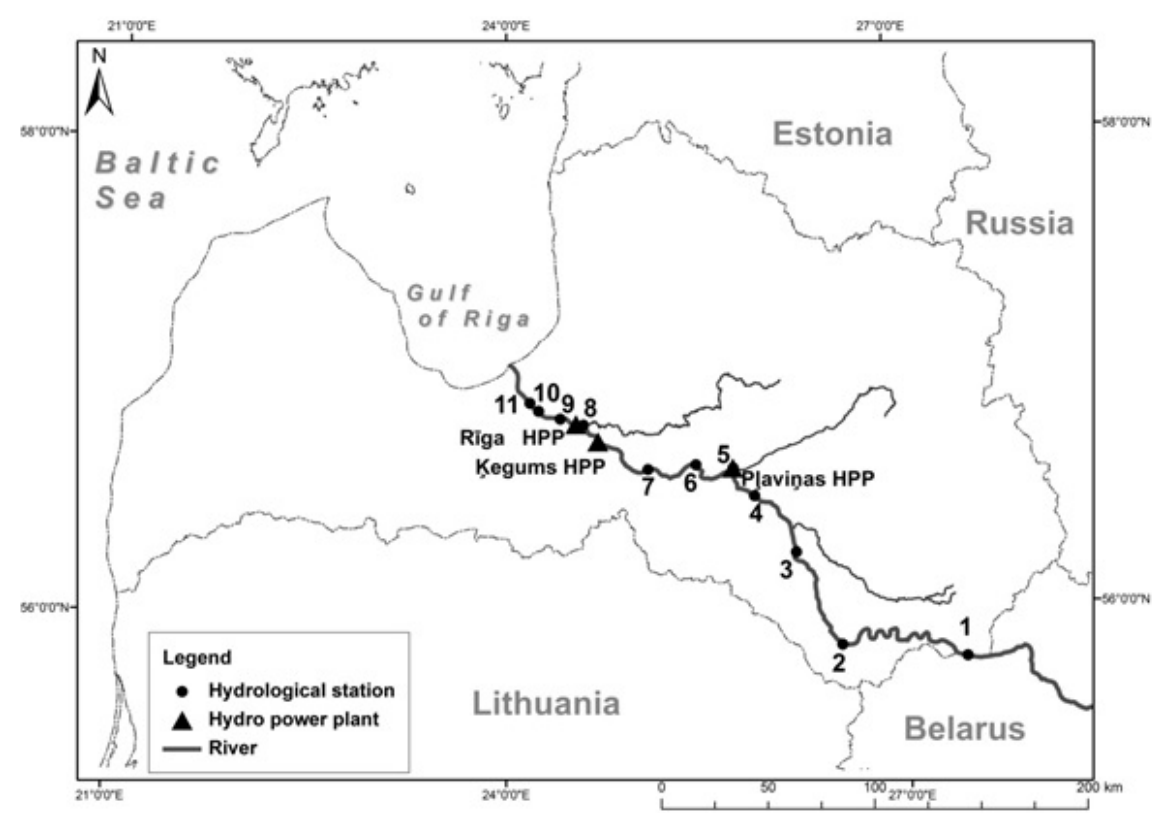

Fig. 1. The Daugava River in the territory of Latvia, location of hydrological stations (HS) and hydro power plants (HPP). Numbers designated ice observation stations according to Table 2 . 
cover before and after construction of the HPP for twenty-

DESCRIPTION OF ICE OBSERVATION STATIONS USED IN THE STUDY

\begin{tabular}{|c|c|c|c|c|}
\hline No. ${ }^{1}$ & $\begin{array}{c}\text { Name of } \\
\text { hydrological } \\
\text { station }\end{array}$ & $\begin{array}{c}\text { Distance from } \\
\text { river mouth, km }\end{array}$ & $\begin{array}{l}\text { Observation } \\
\text { period, year }\end{array}$ & $\begin{array}{l}\text { Description of } \\
\text { impact of HPP }\end{array}$ \\
\hline 1 & Piedruja & 354 & $\begin{array}{c}1944 / 45- \\
2011 / 12\end{array}$ & Not impacted \\
\hline 2 & Daugavpils & 256 & $\begin{array}{c}1921 / 22- \\
2011 / 12\end{array}$ & Not impacted \\
\hline 3 & Jersika & 214 & $\begin{array}{c}1931 / 32- \\
2011 / 12\end{array}$ & Not impacted \\
\hline 4 & Jēkabpils & 172 & $\begin{array}{c}1919 / 20- \\
2011 / 12\end{array}$ & $\begin{array}{l}\text { Not directly } \\
\text { impacted }\end{array}$ \\
\hline 5 & Pḷaviņas & 152 & $\begin{array}{l}1930 / 31- \\
2011 / 12\end{array}$ & $\begin{array}{c}\text { Impacted since } \\
1968\end{array}$ \\
\hline 6 & Dzelzlejas & 124 & $\begin{array}{c}1931 / 32- \\
1965 / 66\end{array}$ & $\begin{array}{l}\text { Not directly } \\
\text { impacted }\end{array}$ \\
\hline 7 & Jaunjelgava & 98 & $\begin{array}{c}1919 / 20- \\
1994 / 95\end{array}$ & $\begin{array}{c}\text { Impacted since } \\
1939\end{array}$ \\
\hline 8 & Ogre & 55 & $\begin{array}{c}1926 / 27- \\
1956 / 57\end{array}$ & $\begin{array}{c}\text { Impacted since } \\
1939\end{array}$ \\
\hline 9 & Lipši & 39 & $\begin{array}{c}1928 / 29- \\
1971 / 72\end{array}$ & $\begin{array}{c}\text { Impacted since } \\
1939\end{array}$ \\
\hline 10 & Maruška & 30 & $\begin{array}{c}1922 / 23- \\
1985 / 86\end{array}$ & $\begin{array}{c}\text { Impacted since } \\
1974\end{array}$ \\
\hline 11 & $\begin{array}{l}\text { Sarkanais } \\
\text { Kvadrāts }\end{array}$ & 22 & $\begin{array}{c}1941 / 42- \\
1986 / 87\end{array}$ & $\begin{array}{c}\text { Impacted since } \\
1974\end{array}$ \\
\hline
\end{tabular}

${ }^{1}$ the number used in Figure 1

A trend was considered significant at the 5\% level, if the test statistic was above 1.96 or below -1.96 .

Statistical analyses were performed using software R 3.0.2. (Anonymous, 2013). The t-test at the significance level of $p<0.05$ (Sokal and Rohfl, 1995) was used to compare the mean freeze-up date, break-up date, and duration of ice year periods.

\section{RESULTS}

Long-term changes of Daugava River ice phenological parameters. Table 3 summarises the data on the ice freezeup and break-up dates and the duration of ice cover. Due to climatic conditions, the river usually freezes up earlier and breaks up later in upper reaches of the Daugava. The data series from the HSs at Piedruja, Daugavpils, Jersika, and Jekkabpils are long (till 2012) and cover the time period when global climate warming was observed at the turn of the $20^{\text {th }}$ to $21^{\text {st }}$ centuries. The observation periods are shorter at the other HSs, and the values of the ice phenology parameters were more or less determined by the construction of the cascade of the HPPs on the Daugava. In upper reaches of the Daugava River (HSs of Piedruja, Daugavpils, and Jersika) there were no years without the formation of ice cover on the river. The highest number of years without formation of ice cover was observed at the Plavingas HS, which was located at a rapid reach prior to the construction of the Plavinas HPP, explaining why the river did not freeze up often in that period of time.

The long-term changes of ice phenology parameters were statistically significant (Mann-Kendall test) for observation data series more than 60 years and extending up to 2012 (Table 4). At the Daugavpils HS (Fig. 2), for example, the ice freeze-up date had a positive trend, while the ice break-up date and duration of ice cover had negative trends. At these HSs, during the last decades, the ice formed later, broke up earlier, and the duration of ice cover was shorter.

Impact of the cascade of hydro power plants upon the Daugava River ice phenology. To assess changes of the phenological parameters of the Daugava River due to the

Table 3

SUMMARY OF ICE FREEZE-UP AND BREAK-UP DATES AND DURATION OF ICE COVER WITH MINIMUM (min), MAXIMUM (max), MEAN AND STANDARD DEVIATION (SD) ${ }^{1}$

\begin{tabular}{|c|c|c|c|c|c|c|c|c|c|c|c|c|c|}
\hline \multirow{2}{*}{$\begin{array}{l}\text { Hydrological } \\
\text { station }\end{array}$} & \multicolumn{4}{|c|}{ Ice freeze-up date } & \multicolumn{4}{|c|}{ Ice break-up date } & \multicolumn{4}{|c|}{ Duration of ice cover, in days } & \multirow{2}{*}{$\begin{array}{c}\text { Number of } \\
\text { years } \\
\text { without } \\
\text { ice cover }\end{array}$} \\
\hline & $\min$ & $\max$ & mean & SD & $\min$ & $\max$ & mean & $\mathrm{SD}$ & $\min$ & $\max$ & mean & SD & \\
\hline Piedruja & 11-Nov & 01-Mar & 21-Dec & 28.8 & 21-Dec & 20-Apr & 24-Mar & 20.2 & 3 & 146 & 92 & 37.0 & 0 \\
\hline Daugavpils & 10-Nov & 14-Feb & 17-Dec & 22.6 & 15-Dec & 21-Apr & 22-Mar & 23.5 & 14 & 150 & 94 & 32.6 & 0 \\
\hline Jersika & 09-Nov & 11-Feb & 14-Dec & 20.2 & 26-Dec & 18-Apr & 24-Mar & 19.2 & 21 & 149 & 100 & 29.1 & 0 \\
\hline Jēkabpils & 30-Oct & 10-Mar & 25-Dec & 30.1 & 10-Dec & 19-Apr & 16-Mar & 30.8 & 0 & 144 & 78 & 42.5 & 9 \\
\hline Pḷavingas & 05-Nov & 03-Feb & 13-Dec & 22.6 & 02-Feb & 18-Apr & 24-Mar & 17.3 & 0 & 159 & 78 & 48.7 & 18 \\
\hline Dzelzlejas & 17-Nov & 25-Feb & 25-Dec & 22.5 & 31-Dec & 17-Apr & 22-Mar & 24.0 & 0 & 145 & 79 & 41.4 & 4 \\
\hline Jaunjelgava & 08-Nov & 24-Feb & 23-Dec & 28.6 & 03-Jan & 20-Apr & 23-Mar & 18.9 & 0 & 153 & 88 & 39.0 & 1 \\
\hline Ogre & 02-Dec & 06-Mar & 06-Jan & 25.1 & $10-\mathrm{Feb}$ & 21-Apr & 22-Mar & 16.6 & 0 & 126 & 68 & 39.5 & 4 \\
\hline Lipši & 24-Nov & 02-Feb & 27-Dec & 18.8 & $10-\mathrm{Feb}$ & 21-Apr & 28-Mar & 15.5 & 0 & 129 & 80 & 37.4 & 4 \\
\hline Sarkanais Kvadrāts & 09-Nov & 05-Feb & 15-Dec & 19.0 & 03-Jan & 20-Apr & 27-Mar & 17.6 & 0 & 142 & 102 & 27.8 & 3 \\
\hline
\end{tabular}

\footnotetext{
${ }^{1}$ The observation periods differ for each hydrological station (see Table 2).
} 
RESULTS OF MANN-KENDALL TEST FOR ICE FREEZE-UP AND BREAK-UP DATES AND DURATION OF ICE COVER

\begin{tabular}{|c|c|c|c|c|c|c|c|}
\hline \multirow{2}{*}{$\begin{array}{c}\text { Name of hydrological } \\
\text { station }\end{array}$} & \multirow{2}{*}{$\begin{array}{c}\text { Number of } \\
\text { samples }\end{array}$} & \multicolumn{2}{|c|}{ Ice freeze date } & \multicolumn{2}{|c|}{ Ice break-up date } & \multicolumn{2}{|c|}{ Duration of ice cover } \\
\hline & & tau & $p$-value & tau & $p$-value & tau & $p$-value \\
\hline Piedruja & 67 & 0.208 & 0.0136 & -0.322 & 0.0001 & -0.332 & 0.0001 \\
\hline Jersika & 77 & 0.167 & 0.0339 & -0.199 & 0.0112 & -0.219 & 0.0051 \\
\hline Jēkabpils & 81 & 0.242 & 0.0008 & -0.178 & 0.0142 & -0.251 & 0.0005 \\
\hline Plaviņas & 64 & -0.364 & .0001 & 0.216 & 0.0051 & 0.333 & .0001 \\
\hline Dzelzlejas & 30 & -0.184 & 0.1280 & 0.255 & 0.0311 & 0.311 & 0.0107 \\
\hline Jaunjelgava & 70 & 0.048 & 0.5598 & -0.103 & 0.2103 & -0.087 & 0.2916 \\
\hline Ogre & 25 & 0.365 & 0.0061 & -0.030 & 0.8301 & -0.318 & 0.0170 \\
\hline Lipši & 37 & 0.150 & 0.1682 & 0.071 & 0.5158 & -0.087 & 0.4313 \\
\hline Maruška & 56 & 0.038 & 0.6801 & 0.037 & 0.6897 & 0.000 & 1.0000 \\
\hline Sarkanais Kvadrāts & 45 & 0.269 & 0.0100 & -0.074 & 0.4809 & -0.247 & 0.0194 \\
\hline
\end{tabular}
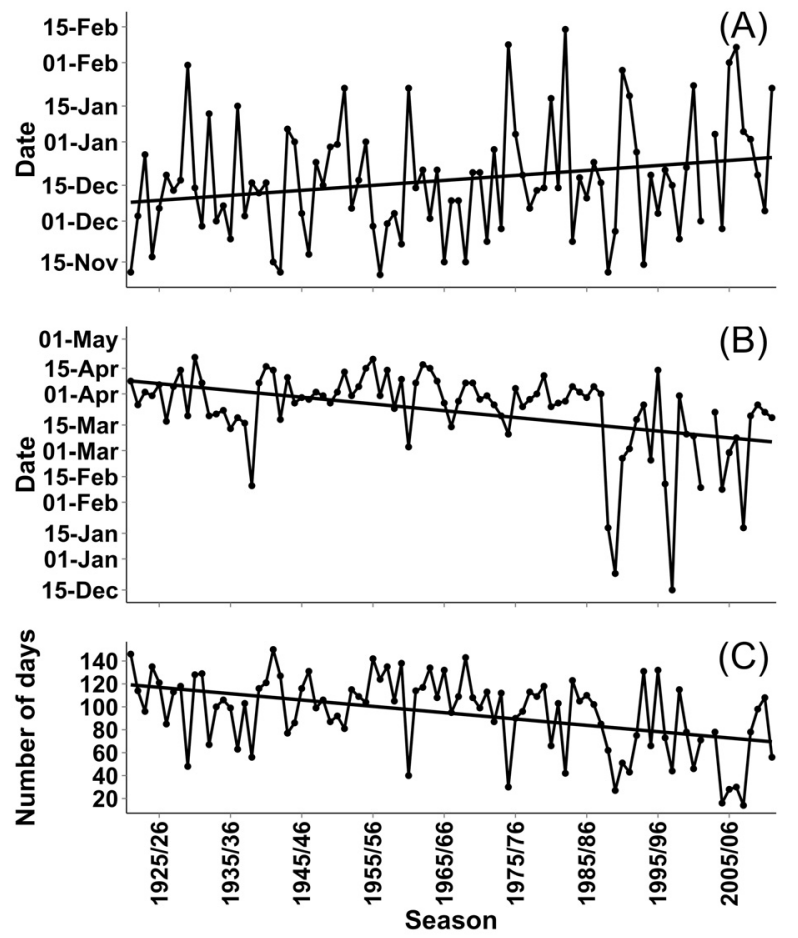

Fig. 2. Long-term changes in the ice freeze-up (A) and break-up (B) dates and the duration of ice cover in days $(\mathrm{C})$ for the Daugavpils Hydrological Station during the period 1921/22 - 2011/12.

construction of the Kegums HPP, two periods were compared: the period 1920/1921-1938/1939, before the HPP construction, and the period 1939/1940-1957/1958, after construction. Significant changes in phenological parameters (Table 5) occurred at the Jaunjelgavas HS, which is located at the Kegums water reservoir $31 \mathrm{~km}$ upstream from the dam. Observations at this station showed that during the period 1939/1940-1957/1958, ice formed earlier (33 days earlier) and broke up later (15 days later), also the duration of ice cover was longer (by 46 days), compared to the period before construction of the dam. Similar changes in ice phenological parameters were observed at the Dzelzlejas HS, which is located above the Kegums water reservoir (57 $\mathrm{km}$ up the dam). At the Ogre and Lipši HSs, which are lo- cated $12 \mathrm{~km}$ and $28 \mathrm{~km}$ below the dam, respectively, after construction of the dam the river froze up later and broke up earlier, and the duration of ice cover was shorter. The impact caused by the HPP on ice formation gradually decreases with distance from the dams.

To assess the impact of the Plavinas HPP, two periods were compared: the period 1947/1948-1967/1968, before the HPP construction, and the period 1968/1969-1987/1988, after construction (Table 6). The impact caused by the Plavinas HPP can only be assessed based on observations at the Plavinas HS (41 km upstream from the dam). There are no HSs located downstream from the dam within the area subject to direct impact of the HPP. The study showed that, following the construction of the HPP, the ice formed 68 days earlier and broke up 69 days later, and the duration of ice cover was 80 days longer at the Plavinas HS. All these changes are statistically significant at the level of $p<0.05$. These dramatic changes can be explained by the fact that the Plavinas HS was located at a rapid reach of the river, which did not often freeze up before construction of the dam. After the construction of the water reservoir in 1968, this river reach freezes up every year.

In 1974, the third HPP on the Daugava River, the Riga HPP, was commissioned, which was built $36 \mathrm{~km}$ from the river mouth. Two study periods were compared: the period 1953/1954-1973/1974, before the HPP construction, and the period 1974/1975-1992/1993, after construction (Table 7). In this case, the impact caused by the Rìga HPP can be assessed using data from the Maruška and Sarkanais Kvadrāts HSs located $6 \mathrm{~km}$ and $12 \mathrm{~km}$ from the dam, respectively. Significant changes in ice phenological parameters were observed at the Maruška HS: ice formed 58 days later, it broke up 41 days earlier, and the duration of ice cover decreased by 91 days. During this period of time, the ice regime was affected both by the HPP and also by global climate warming, particularly at the end of the 1980s. This is confirmed also by observations at the hydrological stations located in upper reaches of the Daugava River (Piedruja, Daugavpils, Jersika HSs). 
IMPACT OF THE ĶEGUMS HPP ON DAUGAVA RIVER ICE PHENOLOGICAL PARAMETERS ${ }^{1}$

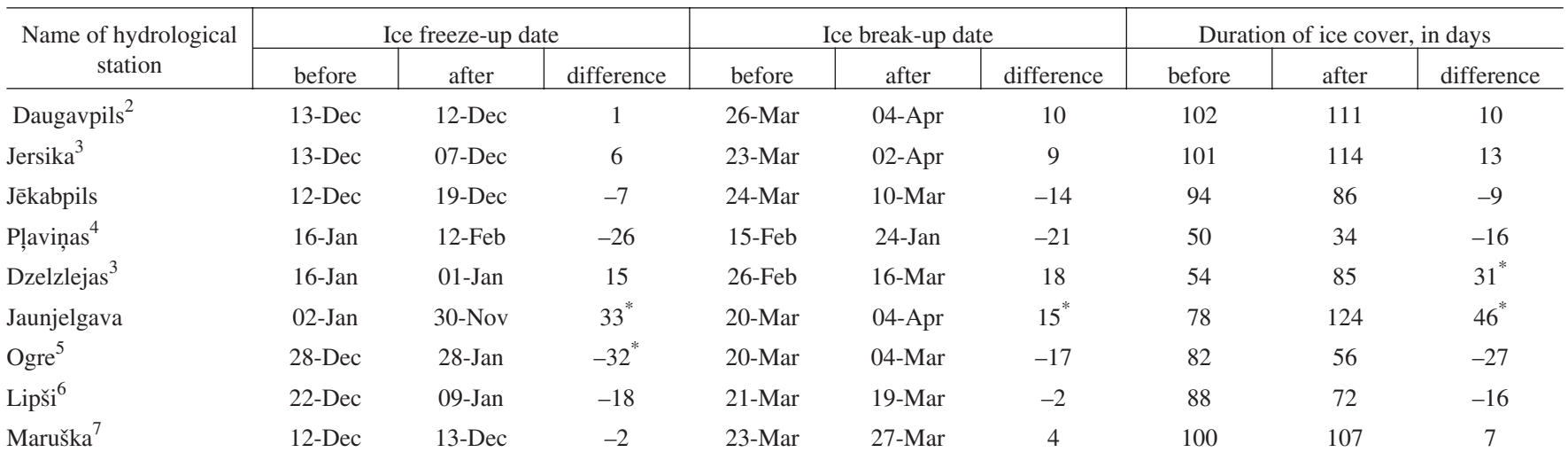

${ }^{1}$ The period 1920/21-1938/39 is before HPP construction, the period 1939/40-1957/58 is after HPP construction, and difference is between the two study periods; ${ }^{2} 1921 / 22-1938 / 39 ;{ }^{3} 1931 / 32-1938 / 39 ;{ }^{4} 1930 / 31-1938 / 39 ;{ }^{5} 1926 / 27-1938 / 39$ and $1939 / 40-1956 / 57 ;{ }^{6} 1928 / 29-1938 / 39 ;{ }^{7} 1922 / 23-1938 / 39 ;{ }^{*}$ statistically significant at $p<0.05$;

Table 6

IMPACT OF THE PL,AVIN,AS HPP ON DAUGAVA RIVER ICE PHENOLOGICAL PARAMETERS ${ }^{1}$

\begin{tabular}{|c|c|c|c|c|c|c|c|c|c|}
\hline \multirow{2}{*}{$\begin{array}{c}\text { Name of hydrological } \\
\text { station }\end{array}$} & \multicolumn{3}{|c|}{ Ice freeze-up date } & \multicolumn{3}{|c|}{ Ice break-up date } & \multicolumn{3}{|c|}{ Duration of ice cover, in days } \\
\hline & before & after & difference & before & after & difference & before & after & difference \\
\hline Piedruja & 12-Dec & 26-Dec & -14 & 04-Apr & 30-Mar & -4 & 113 & 95 & -17 \\
\hline Daugavpils & 14-Dec & 20-Dec & -6 & 03-Apr & 30-Mar & -4 & 109 & 98 & -11 \\
\hline Jersika & 10-Dec & 16-Dec & -5 & 31-Mar & 31-Mar & 0 & 110 & 106 & -4 \\
\hline Jēkabpils & 31-Dec & 30-Dec & 1 & 04-Mar & 30-Mar & $26^{*}$ & 76 & 90 & 14 \\
\hline Pḷaviņas & $11-$ Feb & 05-Dec & $68^{*}$ & 21-Jan & 01-Apr & $69^{*}$ & 35 & 115 & $80^{*}$ \\
\hline Lipši ${ }^{2}$ & 12-Jan & 04-Jan & 8 & 16-Mar & 31-Mar & 15 & 73 & 77 & 4 \\
\hline Maruška $^{3}$ & 11-Dec & 02-Jan & -22 & 29-Mar & 11-Mar & -18 & 109 & 74 & -35 \\
\hline Sarkanais Kvadrāts ${ }^{4}$ & 09-Dec & 24-Dec & $-16^{1)}$ & 01.Apr & 23-Mar & -9 & 113 & 88 & $-26^{*}$ \\
\hline
\end{tabular}

${ }^{1}$ The period 1947/48-1967/68 is before HPP construction, the period 1968/69-1987/88 is after HPP construction and difference is between two study periods; ${ }^{2} 1968 / 69-1971 / 72 ;{ }^{3} 1985 / 86-1938 / 39 ;{ }^{4} 1968 / 69-1986 / 87 ; *$ statistically significant at $p<0.05$;

Table 7

IMPACT OF THE RĪGA HPP ON DAUGAVA RIVER ICE PHENOLOGICAL PARAMETERS ${ }^{1}$

\begin{tabular}{|c|c|c|c|c|c|c|c|c|c|}
\hline \multirow{2}{*}{$\begin{array}{c}\text { Name of hydrological } \\
\text { station }\end{array}$} & \multicolumn{3}{|c|}{ Ice freeze-up date } & \multicolumn{3}{|c|}{ Ice break-up date } & \multicolumn{3}{|c|}{ Duration of ice cover, in days } \\
\hline & before & after & difference & before & after & difference & before & after & difference \\
\hline Piedruja & 07-Dec & 30-Dec & -23 & 03-Apr & 17-Mar & -18 & 117 & 77 & -40 \\
\hline Daugavpils & 08-Dec & 24-Dec & -16 & 02-Apr & 17-Mar & -16 & 113 & 82 & -31 \\
\hline Jersika & 07-Dec & 22-Dec & -15 & 31.mar & 20-Mar & -11 & 113 & 89 & -24 \\
\hline Jēkabpils & 27-Dec & 04-Jan & -8 & 13-Mar & 15-Mar & 2 & 84 & 80 & -4 \\
\hline Maruška $^{2}$ & 05-Dec & 01-Feb & $-58^{*}$ & 30-Mar & 17-Feb & $-41^{*}$ & 118 & 26 & $-91^{*}$ \\
\hline Sarkanais Kvadrāts ${ }^{3}$ & 08-Dec & 28-Dec & -20 & 28-Mar & 25-Mar & -3 & 110 & 85 & -25 \\
\hline
\end{tabular}

\footnotetext{
${ }^{1}$ The period 1953/54-1973/74 is before HPP construction, the period 1974/75-1992/93 is after HPP construction and difference is between two study periods.; ${ }^{2} 1974 / 75-1985 / 86 ;{ }^{3} 1974 / 75-1986 / 87$; * statistically significant at $p<0.05$
}

\section{DISCUSSION}

The processes of freeze-up and break-up of ice differ along the Daugava River among reaches of the stream, due to hydrodynamic conditions of the river-bed where rapid flows interchanges with slower flows, as well as due to climate conditions and the construction of the HPP cascade after the year 1939.

The long-term changes in ice phenological parameters of the Daugava River at the HSs of the studied upper reaches are similar to results of other studies in the Baltic countries 
and in Belarus by Kḷaviņš et al. (2009), in Lithuania by Stonevicius et al. (2008) and Šarauskienè and Jurgelènaitè (2008), and in the Northern hemisphere by Magnuson et al. (2000). During recent decades, rivers have frozen up later and ice broke up earlier, and the duration of ice cover decreased. Changes in the ambient air temperature and the distance from the Baltic Sea are among the major factors determining the formation and the break-up of ice (Šarauskiene and Jurgelènaitè, 2008; Kḷaviňš et al., 2009). Lizuma et al. (2007) found that the annual mean air temperature in Latvia increased by $1.4{ }^{\circ} \mathrm{C}$ during the last 50 years. In the study period from 1950 to 2003, the highest increase in the mean air temperature was recorded in spring (March-May) and early winter (November and December).

Anthropogenic activities, in particular, construction of the HPPs cascade, also affected ice phenological parameters on the Daugava River in the middle and lower reaches. Large water reservoirs are created by construction of a dam. In the reservoirs, ice forms earlier, breaks up later there and the duration of ice cover is longer. Construction of a water reservoir results in less water exchange and more rapid cooling of the upper layers of water. During the cold period of a year, inverse thermal stratification is observed, i.e. water temperature at the bottom is higher than at the surface. In the warm period, water coming from deeper layers of the water reservoir cools the Daugava River. Downstream of the HPP, in the cold period, the process is reversed, i.e. water warms up, freezing is delayed, and early break-up occurs.

The results of our study are similar to those of Glazacheva (Glazacheva, 1963; 1965) on the impact of the Kegums HHP on the freeze-up and break-up dates of the Daugava River during the period from 1928 to 1960 . After construction of the dam, at the Jaunjelgavas HS the river froze up one month earlier and ice broke up four days later, and at the Ogres HS, the Daugava froze up 27 days later and broke up seven days earlier. Until now, no studies have been performed on the impact of the Plavinas HPP and the Riga HPP on changes of Daugava ice phenological parameters. In a study by Šarauskiené and Jurgelènaite (2008), on impact of the Kaunas HPP in Lithuania on ice forming processes in the Nemunas River, the greatest impact of construction of the dam was observed at Kaunas and Lampèdžiai HSs, where ice cover during the study periods (1931-1960 and 1961-1990) decreased on an average by 15 and 5 times, respectively. After construction of the dam, in 1960, the average ice freeze-up date at Druskininkai and Nemajūnai HSs was slightly earlier, whereas at the other HSs the river froze later than in period of 1930/61.

\section{ACKNOWLEDGEMENTS}

We greatly acknowledge the support of the European Social Fund within the project "Support for Doctoral Studies at University of Latvia" and the Latvian Council of Science (grants No. 526/2013 and No. 514/2012) for this research.

\section{REFERENCES}

Anonymous (2007). Climate Change 2007: The Physical Sciences Basis. Intergovernmental Panel on Climate Change. Solomon, S., Qin, D., Manning, M., Chen, Z., Marquis, M., Averyt, K. B., Tignor, M., Miller, H. L. (eds.). Cambridge University Press. Cambridge, UK, and New York. 996 pp.

Anonymous (2013). R: A Language and Environment for Statistical Computing. R Core Team. R Foundation for Statistical Computing, Vienna. Available at: http://www.R-project.org/.

Glazacheva, L. I. (1963). Impact by the Hegums HPP upon the freeze-up and break-up dates of the Daugava [Глазачева, Л. И. Влиание Кегумской ГЭС на сроки замерзания и вскрытия Западной Двины]. Meteorologia i Gidrologia [Метеорология и гидрология], Nr. 8, 38-42 (in Russian).

Glazacheva, L. I. (1965). Ice and thermal regime of rivers and lakes of the Latvian SSR [Глазачева, Л. И. Ледовый и термический режим рек и озер Латвийской ССР]. Zvaigzne, Rīga. 232 pp. (in Russian).

Hirsch, R. M., Slack, J. R. (1984). A nonparametric trend test for seasonal data with serial dependence. Water Res., 20 (6), 727-732.

Hirsch, R. M., Slack, J. R., Smith, R. A. (1982). Techniques of trend analysis for monthly water quality data. Water Res., 18 (1), 107-121.

Kanaviņš, E. (1942). Ledus apstākḷi Daugavā agrāk un šinī ziemā [Ice conditions in the Daugava River earlier and this winter]. Satiksme un Tehnika, Nr. 4, 3-7 (in Latvian).

Kanaviņš, E. (1943a). Ledus apstākḷi Daugavā 1942./43. g. un straumes ledus novērošanai lietotie pan̄ēmieni [Ice conditions in the Daugava in 1942/43 and the methods applied for observations of the stream ice]. Satiksme un Tehnika, Nr. 4, 1-4 (in Latvian).

Kanaviņš, E. (1943b) Ledus iešanas norise 1943. gada pavasarī Daugavā, posmā Jēkabpils-Ķegums, un ledus iziešanas atvieglošanai lietotie panēmieni [The process of ice drifting in the Daugava in spring of 1943 in the section Jèkabpils-Kegums and the methods applied for facilitating the ice moving]. Satiksme un Tehnika, Nr. 6, 1-3 (in Latvian).

Kḷaviņš, M., Briede, A., Rodinov, V. (2009). Long-term changes in ice and discharge regime of rivers in the Baltic region in relation to climatic variability. Climate Change, 95, 485-498.

Lizuma, L., Kḷaviņš, M., Briede, A., Rodinovs. V. (2007). Long-term changes of air temperature in Latvia. In: Kḷaviņ̌̌, M. (Ed.). Climate Change in Latvia. Academic Publishers, University of Latvia, Riga, pp. $11-19$.

Magnuson, J. J., Robertson, D. M., Benson, B. J., Wynne, R. H., Livingstone, D. M., Arai, T., Assel, R. A., Barry, R. G., Card, V., Kuusisto, E., Granin, N. G., Prowse, T. D., Stewart, T. D., Vuglinski V. S. (2000). Historical trends in lake and river ice cover in the Northern hemisphere. Science. 289, 1743-1746.

Pastor, A. A. (1987). Ice congestions and ice jams on the Daugava River in the section Jekkabpils-Pḷavinas. In: Publications of the Centre of the Hydrometeorology. Hydrometeorology of the Latvia USS and the Gulf of Riga, Vol. 1 (21). [Пастор, А. А. Зажоры и заторы льда на р. Даугаве на учаске г. Екабпилс - г. Плявиняс. Сборник работ гидрометеологического иентра, Гидрометеорология Латвийской ССР и Рижского залива, выпуск 1 (21). Leningrad, Hydrometeoizdat, pp. 107-120. (in Russian).

Šarauskienè, D., Jurgelènaitè, A. (2008). Impact of climate change on river ice phenology in Lithuania. Environ. Res. Eng. Manag., 4 (46), 13-22.

Sokal, R. R., Rohlf, F. J. (1995) Biometry: The Principles and Practice of Statistics in Biological Research. $3^{\text {rd }}$ edition. W. H. Freeman and Co, New York. 778 pp.

Solomon, B. G., Knut, T. A. (2011). Investigation of river ice regimes in some Norwegian water courses. In: CGU HS Committee on River Ice Processes and the Environment, $16^{\text {th }}$ Workshop on River Ice, 18-22 September 2011, Winnipeg, Manitoba, pp. 1-17. 
Stakle, P. P. (1933). Conditions of the ice regime of the Latvian rivers, in particular the Daugava river. In: IV Hydrological Conference of the Baltic States, September 1933 [Стакле, П. П. Условия ледового режима Латвийских рек, в частности р. Даугавы (Зап. Двина)]. IV Гидрологическая конференция Балтиских стран, сентябрь 1933. г.]. Leningrad, pp. 1-32 (in Russian).

Received 9 September 2014
Stakle, P., Kanaviňš, E. (1941). Latvijas iekšzemes ūdenu hidrometriskie pétījumi no 1929. g. 1. XI lìdz 1940. g. 31. X [Hydrometric Studies of the Inland Waters of Latvia from 01.11.1929 to 31.10.1940]. Jūrniecības pārvaldes izdevums, Rīga. 624 lpp. (in Latvian).

Stonevicius, E., Stankunavicius, G., Kilkus, K. (2008). Ice regime dynamics in the Nemunas River, Lithuania. Climate Res., 36 (1), 17-28.

Ziverts, A., Zakis, G., Jauja, J. (2000). Ice processes in the Daugava River. In: Nilsson, T. (Ed.). Proceedings of XXI Nordic Hydrological Conference Report No. 46, Volume 2, Uppsala, Sweden, pp. 638-645.

\section{HIDROELEKTROSTACIJU KASKĀDES IETEKME UZ DAUGAVAS LEDUS FENOLOĢIJAS ILGTERMIN̦A IZMAIN̦ĀM}

Šajā publikācijā ir apkopoti pētījuma rezultāti par Daugavas ledus fenoloğijas parametru (ledus veidošanās datums, ledus uzlūšanas datums un ledstāves ilgums dienās) ilgtermiņa izmaiņām un triju hidroelektrostaciju (Rīgas, Ķeguma un Pḷaviņu) ietekmi laika posmā no 1919./1920. līdz 2011./2012. gadam, izmantojot matemātiskās statistikas metodes. Pētījums parādīja, ka ledus fenoloǵijas parametru ilgtermiņa izmaiņas ir statistiski ticamas četrās hidroloğiskajās novērojumu stacijās (Piedruja, Daugavpils, Jersika, Jēkabpils), ja novērojumu periods ir garāks par 60 gadiem un novērojumi veikti līdz 2012. gadam. 20. un 21. gadsimta mijā globālā klimata pasiltināšanās rezultātā ir novērojamas šādas tendences: ledus izveidošanās datumam ir pozitīvs trends (t.i., ledus veidojas vēlāk) un ledus uzlūšanas datumam un ledstāves ilgumam ir negatīvs trends (t.i., ledus uzlūst ātrāk un ledstāves ilgums ir ìsāku laika periodu). Lai pētītu hidroelektrostacijas ietekmi uz ledus fenoloǵijas parametru izmain̄ām, tika salīdzināti 20 gadu ilgi laika periodi pirms un pēc hidroelektrostacijas uzbūvēšanas. Pētījums parādīja, ka hidroloğiskajās stacijās, kas atrodas augšpus aizsprosta ūdenskrātuvē, pēc hidroelektrostacijas uzbūvēšanas ledus izveidošanās notiek ātrāk, uzlūšana iestājas vēlāk un ledstāves ilgums palielinās. Savukārt hidroloğiskajās stacijās, kas atrodas lejpus aizsprosta, ir novērojams pretējs ledus režīma process - ledus izveidojas vēlāk, uzlūst ātrāk un ledstāves ilgums samazinās. Ledus fenoloǵisko parametru izmaiṇu ilgums atkarīgs no hidroloğiskās stacijas atrašanās attāluma no aizsprosta. Jo tā atrodas tālāk no aizsprosta, jo mazāku ietekmi uz ledus fenologíiskajiem novērojumiem atstāj hidroelektrostacijas darbība tas ir saistīts ar ūdens termiskā režīma izmaiṇām. 